\title{
Social Support, Impression Management and Well-Being Following a Disaster: A Literature Review and Some Conceptual Considerations
}

\author{
Nur Haffiza Binti Rahaman, Che Su Mustaffa, and Taib Ariffin
}

\begin{abstract}
In this paper, the influence of social support and impression management on the well-being of flood victims in Malaysia will be discussed. The paper starts with a definition of all the variables. Literature review so far shows that there is a limited research on victims of flood disaster in Malaysia. This paper will explore perceptions of flood victims toward social support provided by the government and analyze flood victims' well-being and impression management. Finally, a conceptual framework will be proposed in accordance with the flood situation in Malaysia. The conceptual framework includes three main ideas, namely social support, impression management and well-being. This paper contributes to the study of disaster by providing a conceptual framework, which can be used to further investigate variables that influenced well-being because of disaster.
\end{abstract}

Index Terms-Well-Being, social support, impression management, disaster

\section{INTRODUCTION}

Natural disasters such as droughts, earthquakes, epidemics, floods and wind storms will damage well-being, both in their immediate and long-term aftermath, and because of the insecurity of exposure to disasters is in itself harmful to people who avoid risks [1]. Floods are some of the contributing factors to high level of stress and other psychological problems in individuals.

Physical effects such as loss and destruction of properties and life are among the many consequences of natural disasters. These impacts may last for a short or long term. Victims are often struggling hard to accept and cope with these negative effects [2].

Well-being is conceived in different ways but generally refers to optimal psychological functioning and experience [3]. Well-being is something that makes a person feel fun, happy and feel that their life is meaningful [4]. Mohammed Fadhil [5] argued that well-being is in fact an attempt to solve the problems and improve the quality of human life to be living safely, healthily and comfortably physically, socially and psychologically. The Malaysian well-being is defined as encompassing personal development, healthy lifestyles, access and freedom to pursue knowledge and standards of

Manuscript received June 1, 2013; revised August 5, 2013. The authors wish to thanks the Ministry of Higher Education Malaysia for funding this study under Long Term Research Grant Scheme (LRGS/b-u/2012/UUM/TeknologiKomunikasidanInformasi).

Nur Haffiza Binti Rahaman and Che Su Binti Mustaffa are with the Universiti Utara Malaysia, Malaysia (e-mail: budakampung87@yahoo.com; chesu402@uum.edu.my).

Mohd Taib Ariffin is with the University Pendidikan Sultan Idris, Tanjong Malim, Perak, Malaysia (e-mail: taib@upsi.edu.my). living beyond the basic needs of individuals and their psychological needs, to achieve the level of social welfare in accordance with the national aspirations [6].

The Government plays an important role in relief distribution and rehabilitation activities during disasters [7]. One of the important reliefs is social support. Social support can be defined as social interactions that provide individuals with actual assistance or embed them into a web of social relationships perceived to be caring and readily available in time of need [8]. Cobb [9] said that social support is equally perceived information that people believe they are perceived to be caring and appreciating, and they also belong to a network of communication and mutual obligation. Social support is a growing body of evidence, which supports the notion that supportive social relationships are beneficial for physical and emotional health [10].

\section{WELL-BEING}

Norizan [11] in the study of the well-being divided well-being into two categories; the objective quality of life and subjective quality of life. The objective quality of life means living needs that can be enjoyed by individuals and can be seen on the surface such as income, housing, health and education. The subjective quality of life is a life of satisfaction and pleasure felt by individuals such as feeling good and grateful to have a good job, having successful kids and a happy family.

Siti Fatimah [12] explained that the concept of the welfare of living or quality of life is not simply measured by material values just like home ownership, vehicle, and a high level of education, but it also covers the material aspect such as the feeling of love, warmth between individuals, compassion and always feel relieved.

Xiangdong [13] found that the earthquake adversely affected the victims' quality of life in physical, psychological and environmental domains at 3 months and psychological and environmental domains at 9 months, after the disaster. When compared with the non-affected comparison group, the victims suffered significantly more psychological distress in terms of depression and anxiety. These results demonstrate that exposure to a natural disaster is associated with multidimensional impairment in well-being.

Hommerich [14] studied the preliminary results of an analysis of trust in governmental institutions and social networks after the disaster of 11 March 2011, as well as an investigation of the implication of such trust resources for subjective well-being. Using data from a postal survey carried out in the Tohoku and Kanto regions in September 
2011, differences in trust resources are explored by regional proximity to the disaster area as well as by personal affliction. Levels of social trust prove to be generally high, while trust in governmental institutions is low, especially when personally affected by the disaster. The results of this study indicate that trust resources are shown to contribute positively to subjective well-being and thus to constitute an important asset in the process of coping with disaster.

Becchetti and Castriota [15] investigated the effects of the 2004 Tsunami on a sample of 200 damaged (the treatment group) and 105 non-damaged (the control group) of microfinance borrowers. The findings showed that the severe loss of income of damaged borrowers only partially explains the dip in well-being. This is because the latter is also related to economic losses not measured by current income and psychological or emotional effects. The role of risk on the Tsunami impact partially captured by the interaction of the damage dummy with borrowers' productive activity was found.

\section{SOCIAL SUPPORT}

Cohen [16] identified three types of social support selected for representation in initial item pools, namely instrumental, informational, and emotional support. Instrumental support refers to the perceived availability of people who can provide functional aid in completing daily tasks if needed. Informational support refers to the availability of people who can provide information or advice needed to solve problems that arise. Emotional support refers to the availability of people to listen to one's problems with empathy, caring, and understanding.

A study was conducted by Jason, Davis, and Ferrari [17] on social support and self-efficacy among the Oxford House occupants. Convalescent home or Oxford House is a relief effort that combines 12 measures in community-based support network for reducing drug abuse. The results showed that the changes or lack of desire to engage in drug use could be reduced by social support. Life has improved the bond of community relationships with other individuals who have the same goal, which is drug-free. Community life also increases self-efficacy to abstain from drug use.

Research by Drogendijk et al. [18] examined the relationship between lack of social support, immigration status and the status of the victim, as well as the differences in support between immigrants and native Dutch with posttraumatic stress disorder (PTSD) after a disaster. The results showed that affected immigrants more often lack of variety of perceived social support compared with affected Dutch natives. However, there was no difference in support between the affected immigrants and unaffected immigrants. Immigrants with PTSD differed on only two out of six aspects of support from the Dutch natives with PTSD.

Sarah et al., [19] studied that prehurricane perceived social support protects against psychological distress among low-income mothers. It indicates that predisaster social support can decrease both exposure to natural disasters and the negative psychological effects of natural disaster exposure. These findings underscore the importance of bolstering the post-disaster social support networks of low-income mothers. They had examined the influence of pre-disaster perceived social support on post-disaster psychological distress and whether performance-based scholarships affected academic achievement, health and well-being among survivors of Hurricane Katrina. The results provide partial support for the hypothesized model. Although pre-disaster perceived social support did not exert a direct effect on post-disaster psychological distress, the indirect effects of all 3 proposed mediators were significant.

\section{IMPRESSION MANAGEMENT}

Impression management has long been recognized as an important aspect of corporate leadership [20]. A large and growing literature in organizational theory and strategy has examined how corporate leaders manage the impressions of organizational constituents in the wake of image threatening events such as the disclosure of low firm performance, accidents or bankruptcy, or following the announcement of controversial policies such as generous CEO pay plans or corporate diversification [21].

Jones and Pittman [22] developed a broad taxonomy aimed at capturing the wide variety of impression management behaviors identified by earlier researchers in an effort to facilitate the organization of management research. Their study is one of the first to highlight the importance of impression management behaviors in organizational setting. They had identified five theoretical groupings of impression management strategies that individuals commonly used. Their taxonomy included self-promotion, ingratiation exemplification, intimidation and supplication, which had been identified as tactics that can be performed to create an image designed to enhance one's career.

Most impression management research has been conducted at the dyadic level and has focused on the types of strategies employed [23], motivations behind the use of each strategy [24], individual characteristics of agents and targets related to the use of impression management [25] and reactions of targets to impression management behaviors [26].

\section{SOCIAL SUPPORT AND WELL-BEING}

Social support is one of the well-documented psychosocial factors influencing physical well-being outcomes [27]. Kaniasty [28], in his research of postdisaster social support and aid unfolding within the first 12 months after the flood, reported that the indicators of postdisaster social bitterness, operational as dissatisfaction with aid and interpersonal and community animosities and disagreements, were predictive of lower levels of social psychological well-being. He also suggested that postdisaster relief and intervention programs should consider helping survivors maintain or even argue their perceptions of being supported and their trust in the benefits of belonging to a valued social group and community.

Brouwers, Ever, and Tomic [29] developed the Teacher Interpersonal Self-Efficacy scale which consists of three subscales, namely Perceived Self-Efficacy in Classroom Management, Perceived Self-Efficacy in Eliciting Support from Colleagues, and Perceived Self-Efficacy in Eliciting 
Support from Principals. This is a no recursive model with relationships between perceived lack of social support, perceived self-efficacy in eliciting support at the workplace and the three successive burnout dimension-emotional exhaustion. Depersonalization and personal accomplishment were tested on a sample of 277 secondary-school teachers in The Netherlands. Results showed that the teachers' perceived lack of support from colleagues and principals had a significant effect on their self-efficacy beliefs in eliciting support from them, while these self-efficacy beliefs were shown to predict their level of burnout. The hypothesized feedback loop was also confirmed. Teachers' level of burnout predicted the extent to which they feel lack of support. An additional effect of the personal-accomplishment dimension of burnout on perceived self-efficacy was suggested. It was concluded that perceived self-efficacy in eliciting support at the workplace is a usable construct in the prediction of teacher burnout.

Brown et al. [30] examined health-related quality of life in women and men in the wake of Hurricanes Katrina and Rita using a prospective design. The study sample was composed of 59 persons for prehurricane Waves 1 and 2. The inclusion of two waves of testing allowed longitudinal inferences on SF-36 scores from prehurricane baseline (January to August 2005 ) to immediate impact (Wave 1 from October to January 2006) and postdisaster recovery (Wave 2 from March to November 2006) periods, a strength of this study. The findings provide new evidence of time of testing effects in measures of physical function, bodily pain, and the physical health component score. Participants perceived that social support ratings were relatively high and did not change from Wave 1 to Wave 2 testing, implying that their perceptions of social support in postdisaster context are stable over time.

\section{IMPRESSION MANAGEMENT AND WELL-BEING}

The presentation of government is very important for the flood victims' well-being. Self-presentation or impression management is the process by which people seek to influence the images others form of them. Goffman [31] argued that people manage the impressions others have of them by communicating their desired identity to obtain particular outcomes in an interaction. When individuals find themselves in situations where they want to present themselves as competent, they are likely to convey self-promoting messages that emphasize relevant personal attributes and achievements corresponding to what extensions they think others have of a competent person. The impressions that people make have important implications of how others perceive, evaluate and treat them, and can influence their own self-concepts as well as their psychological well-being [32].

Most researchers study impression management in organizations, job satisfaction and performance. According to Pollach and Kerbler [33] in their study of impression management in the US and European CEO profiles, the results indicate that impression management is more prevalent in North American CEO profiles. CEO's involvement in political activities plays a bigger role in the construction of CEO's competence in North America. Whereas CEO's profiles of North American companies show
CEOs as active participants in social, political and public life, European CEOs are presented as primarily business-focused.

Westphal et al. [34] examined the determinants and consequences of impression management (IM) support in communication between CEOs and journalists. The data are from large and midsized public US companies from 1999 to 2007, including the original survey data from a large sample of CEOs and journalists. The results indicate that CEOs of other firms provide positive statements about a focal CEO's leadership and strategy and external attributions for low performance at the focal CEO's firm.

\section{PROPOSED MODEL}

Based on the literature review, we can conclude that social support, impression management and well-being have not been studied in the context of flood disaster in Malaysia. Therefore, a framework could be proposed in accordance with the flood situation in Malaysia as in Fig. 1. Based on the framework, social support and impression management has an important role in enhancing the flood victims' well-being.

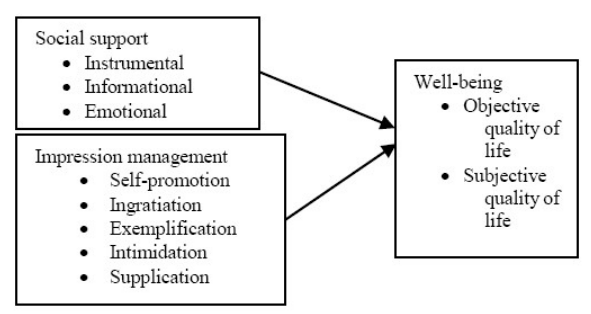

Fig. 1. Conceptual framework.

\section{CONCLUSION}

Many studies have been conducted on disasters, but there is still a limited research on floods in Malaysia especially in the context of communication. This paper proposed a framework to explore perceptions of the flood victims toward social support provided by the government and analyze the flood victims' well-being, social support and impression management of the flood situation in Malaysia.

\section{REFERENCES}

[1] J. D. Johnson, "Natural disasters and adaptive capacity," Capacity Building and Competitivenes, vol. 6, 2004

[2] R. Nasir, A. Z. Zainah, and R. Khairudin, "Psychological effects on victims of the Johor flood 2006/2007," Asian Social Science, vol. 8, no. 8, pp. 126-133, 2012.

[3] R. M. Ryan and E. L. Deci, "On happiness and human potentials: A review of research on hedonic and eudaimonic well-being," Annual Review of Psychology, vol. 52, pp. 141-166, 2001.

[4] R. Renwick. (2006). The quality life model. [Online]. Available: http://www.utoronto.ca/qol/concepts. htm.

[5] F. N. Mohammed, "Penilaian dampak pembangunan ke arah kesejahteraan masyarakat," Penilaian Dampak Sosial, Kuala Lumpur: Utusan Publication \& Distributor, 2003.

[6] U. P. Ekonomi, "Usaha ke arah peningkatan kualiti hidup," Kualiti hidup Malaysia 99, Jabatan Perdana Menteri Malaysia, Kuala Lumpur: Percetakan Nasional Berhad, 1999.

[7] K. Ahmad, T. A. Naveed, S. Ullah, and T. Rashid, "Role and performance of government and NGOS in relief assistance: A case study of 2005 earthquake," Interdisciplinary Journal of Contemporary Research in Business, vol. 3, no. 2, pp. 1726-1736, 2011.

[8] A. N. Drogendijk, P. G. V. D. Velden, B. P. R. Gersons, and R. J. Kleber, "Lack of perceived social support among immigrants after a 
disaster: Comparative study,” The British Journal of Psychiatry, vol. 198, pp. 317-322, 2011.

[9] S. Cobb, "Social support as a moderator of life stress," Psychosomatic medicine, vol. 38, no. 5, pp. 300-314, 1976

[10] L. F. Berkman and T. Glass, "Social integration, social networks, social support and health," in: L. F. Berkman \& I. Kawachi (Eds.), Social Epidemiology, New York, NY: Oxford University Press, pp. $137-173,2000$.

[11] N. A. Ghani, "Kualiti hidup penduduk pulau Negeri Terengganu: Satu kajian di Pulau Redang dan Pulau Perhentian," Thesis Ph.D, Kolej Universiti Sains dan Teknologi Malaysia, 2003.

[12] S. F. Abdul Rahman. (2006). Kriteria kualiti hidup berkeluarga [Online]. http://www.ikim.gov.my/bm/paparmedia.php?key=781.

[13] X. D. Wang, L. Gao, H. B. Zhang, C. Z. Zhao, Y. C. Shen, and N. Shinfuku, "Post earthquake quality of life and psychological well-being: Longitudinal evaluation in a rural community sample in northern China," Psychiatry and Clinical Neurosciences, vol. 54, pp. 427-433, 2000.

[14] C. Hommerich, "Trust and subjective well-being after the great east Japan earthquake, tsunami and nuclear meltdown: preliminary results," International Journal of Japanese Sociology, no. 21, pp. 1-20, 2012.

[15] L. Becchetti and S. Castriota, "The effects of a calamity on income and wellbeing of poor microfinance borrowers: The case of the 2004 tsunami shock," Journal of Development Studies, vol. 46, no. 2, pp 211-233, 2010

[16] S. Cohen, "Social relationships and health," American Psychologist, vol. 59, pp. 676-684, 2004.

[17] L. A. Jason, M. I. Davis, and J. R. Ferrari, "The need for substance abuse after-care: Longitudinal analysis of Oxford House," Addictive Behaviors, vol.32, pp.803-818, 2007.

[18] A. N. Drogendijk, P. G. Velden, B. P. R. Gersons, and R. J. Kleber, "Lack of perceived social support among immigrants after a disaster: Comparative study," The British Journal of Psychiatry, vol. 198, pp. 317-322, Doi: 10.1192/bjp.bp.110.077644, 2011.

[19] S. R. Lowe, C. S. Chan, and J. E. Rhodes, "Pre-hurricane perceived social support protects against psychosocial distress: A longitudinal analysis of low-income mothers," Journal of Consulting and Clinical Psychology, vol. 78, no. 4, pp. 551-560, 2010.

[20] J. Pfeffer, "Management as symbolic action: The creation and maintenance of organizational paradigms," in L. L. Cummings and B. M. Staw (eds.), Research in Organizational Behavior, vol. 3, pp. 1-52, Greenwich, CT: JAI Press, 1981

[21] R. I. Sutton and A. L. Callahan, "The stigma of bankruptcy: Spoiled organizational image and its management," Academy of Management Journal, vol. 30, pp. 405-436, 1987.

[22] E. E Jones and T. S. Pittman, "Toward a general theory of strategic self-presentation," in J. Suls (Ed), Psychological Perspective on the Self, Hillsdale, NJ: Lawrence Erlbaum, pp. 231-261, 1982.

[23] D. M. Buss, M. Gomes, D. S. Higgins, and K. Lauterbach, "Tactics of manipulation," Journal of Personality and Social Psychology, vol. 52, 1219-1229, 1987.

[24] R. M. Arkin, A. J. Appleman, and J. M. Berger, "Social anxiety, self-presentation, and the self-serving bias in causal attribution," Journal of Personality and Social Psychology, vol. 38, pp. 23-35, 1980.

[25] R. F. Baumeister and E. E. Jones, "When self-presentation is constrained by the target's knowledge: Consistency and compensation," Journal of Personality and Social Psychology, vol. 36, pp. 608-618, 1978.

[26] B. R. Schlenker and M. R. Leary, "Social anxiety and self-presentations: A conceptualization and model," Psychological Bulletin, vol. 92, pp. 641-669, 1982.

[27] B. N. Uchino, Social Support and Physical Health: Understanding the Health Consequences of Our Relationship, New Haven, CT: Yale University Press, 2004.

[28] K. Kaniasty, "Predicting social psychological well-being following trauma: The role of post-disaster social support," Psychological Trauma: Theory, Research, Practice and Policy, vol. 4, no. 1, pp. 22-23, 2012.

[29] W. J. G. Evers, A. Brouwers, and W. Tomic, "Burnout and self-efficacy: A study on teachers' beliefs when implementing an innovative educational system in the Netherlands," British Journal of Educational Psychology, vol. 72, pp. 227-243, 2002.

[30] J. S. Brown, K. E. Cherry, L. D. Marks, E. M. Jackson, J. Volaufova, C. Lefante, and S. M. Jazwinski, "After Hurricanes Katrina and Rita: Gender differences in health and religiosity in middle-aged and older adults," Health Care for Women International, vol. 31, pp. 997-1012, 2010.
[31] E. Goffman, The Presentation of Self in Everyday Life, London: Penguin, 1959.

[32] M. R. Leary and R. M. Kowalski, "Impression management: A literature review and two component model," Psychological Bulletin pp. $34-47,1990$.

[33] I. Pollach and E. Kerbler, "Appearing competent: A study of impression management in U.S. and European CEO profiles," Journal of Business Communication, vol. 48, no. 4, pp. 355-372, 2011.

[34] J. D. Westphal, S. H. Park, M. L. McDonald, and M. L. A. Hayward, "Helping other CEOs avoid bad press: social exchange and management support among CEOs in communications with journalists," Administrative Science Quarterly, vol. 57, no. 2, pp. 217-268, 2012.

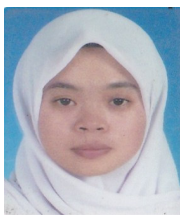

Nur Haffiza Rahaman was born in Kelantan in 1987. She obtained a bachelor of media technology in Universiti Utara Malaysia in 2011 and a Master of Science (Managerial Communication) in 2013. Currently, she is doing a Ph.D. in Communication at Universiti Utara Malaysia. She assistant at Universiti Utara Malaysia.

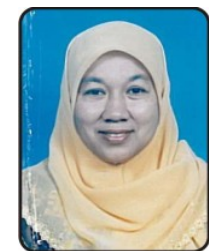

Che Su Mustaffa holds a a Ph.D. in organizational communication, Universiti Utara Malaysia/University of Memphis, M.Sc. (Journalism and Mass Communication), Iowa State University, USA, and bachelor of arts in communication (minor History), Universiti Kebangsaan Malaysia. She possesses vast experience with more than 23 years of working experience in the field of communication.

Prof. Dr. Che Su joined Universiti Utara Malaysia as a tutor in 1988 and became a lecturer in 1990 and was promoted to associate professor in 2000 . Currently, she is a professor of communication at the College of Arts and Sciences, Universiti Utara Malaysia. Beside academic responsibilities, she has also held several administrative positions such as a the chairperson for graduate studies, deputy dean (academics), dean, and chairperson for the communication program. At present, she is a deputy dean at Awang Had Salleh Graduate School of Arts and Sciences, College of Arts and Sciences, Universiti Utara Malaysia.

Her research interests are organizational communication such as communication satisfaction, communication technology, family communication, and Malaysian Malay communication style. Her written works have appeared in refereed journals such as Journal Analysis, Journal of Intercultural Communication Research, Intercultural Communication Studies, and Corporate Communications: An International Journal, and Human Communication.

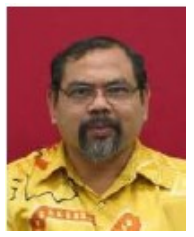

Mohd Taib Ariffin was born in Teluk Intan Perak in 10th June 1956. Bachelor holder in communication from University Kebangsan Malaysia, Bangi in 1983. Doing master in interpersonal communication in Ohio University, USA at 1989.

He has worked as Training and Investigating Officer, in National Productivity Center, Petaling Jaya, Selangor, Malaysia (1983-1987, lecturer and Associate Professor, Northern University of Malaysia, Sintok, Kedah, Malaysia (1987-2001) and Associate Professor, University Pendidikan Sultan Idris, Tanjong Malim, Perak, Malaysia (2001-today).

He and Mohd Taib Ariffin, Che Su Mustaffa \& Rosli Muhammed, AIDS: Pendedahan Kepada Media, Pengetahuan Tentang AIDS dan Tindakan Terhadap Kempen-kempen Kesihatan di Kalangan Masyarakat (2002), Mohd Taib Ariffin, Mohd Shafie Abu Bakar, Khairuddin Lim Abdullah, Osman Jusoh \& Bahijah Abas, Membentuk Usahawan Bumiputra Melalui Pendidikan (2006). Che Su Mustaffa, Mohd Foad Sakdan, Najib Ahmad Marzuki, Muhamad Shukeri Khalid \& Mohd Taib Ariffin, Flood Relief Management: A Psychosocial Dynamic ModelFor Predicting Well-being (on going), Khairul Azam Bahari, Mohd Taib Ariffin \& Mohamed Zin Nordin, Penggunaan Bahasa Melayu Piawai Dalam Kalangan Ahli-ahli Akademik dan Media (on going).

He has served as Academik Board Member of Kolej Menara Jaya, Kampar Perak (2006 - now), Panel of Assessors, Malaysia Qualification Agency (MQA) (2000-now). Has Supervised a lot of Master and undergraduate thesis. He also presented a lot of seminar papers at both national and international level. 